

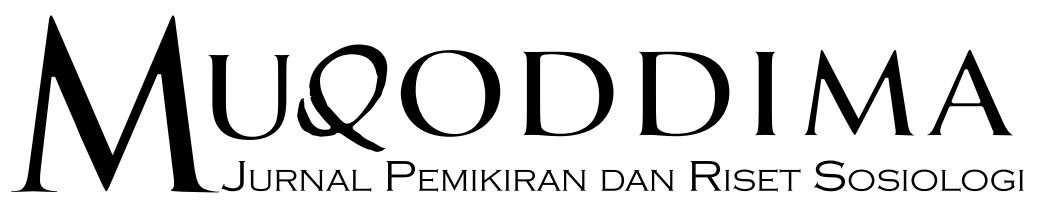




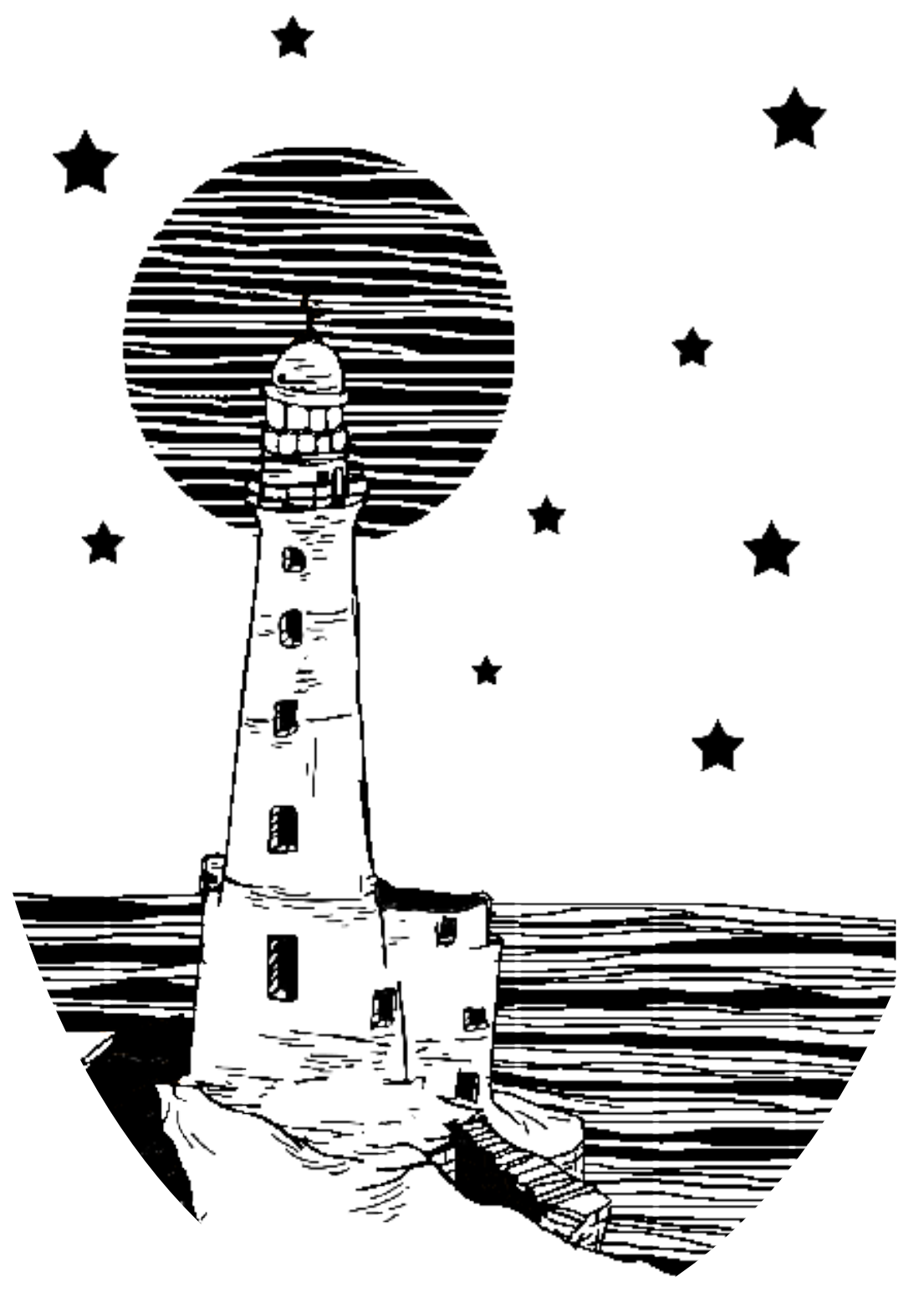




\section{MUgoddima \\ JuRnal PEMIKIRAN DAN RISET SOSIOLOGI}

Vol. 1 No. 2 Desember 2020

ISSN 2745-7168 (DARING)

\section{Editor in Chief}

Eneng Darol Afiah, Universitas Nahdlatul Ulama Indonesia Jakarta

\section{Managing Editor}

Naeni Amanulloh, Universitas Nahdlatul Ulama Indonesia Jakarta

\section{Editor}

Amsar A. Dulmanan, Universitas Nahdlatul Ulama Indonesia Jakarta

Pangeran P.P.A. Nasution, Universitas Malikussaleh

Muhammad Nurul Huda, Universitas Nahdlatul Ulama Indonesia Jakarta

Muhammad Mustafid, Universitas Nahdlatul Ulama Yogyakarta

Mujtaba Hamdi, Universitas Nahdlatul Ulama Indonesia Jakarta

Fikri Tamau, Universitas Pembangunan Nasional Veteran Jakarta

Hanifa Maulidia, Sekolah Tinggi Imigrasi

Dewi Anggraeni, Universitas Nahdlatul Ulama Indonesia Jakarta

Muhammad Nurun Najib, Universitas Nahdlatul Ulama Indonesia Jakarta

R.M. Joko P. Mulyadi, Universitas Nahdlatul Ulama Indonesia Jakarta

Moh. Faiz Maulana, Universitas Nahdlatul Ulama Indonesia Jakarta

\section{Reviewer}

Achmad Munjid, Universitas Gajah Mada, Yogyakarta, Indonesia

Ahmad Suaedy, Universitas Nahdlatul Ulama Indonesia, Jakarta, Indonesia

Syamsul Hadi, Universitas Nahdlatul Ulama Indonesia, Jakarta, Indonesia

Moh. Yasir Alimi, Universitas Negeri Semarang, Semarang, Indonesia

Nadiatus Salama, Universitas Islam Negeri Walisongo, Semarang, Indonesia

Anton Novenanto, Universitas Brawijaya, Malang, Indonesia

Akhmad Ramdhon, Universitas Sebelas Maret, Surakarta, Indonesia

Imam Ardhianto, Universitas Indonesia, Jakarta, Indonesia

Achmad Fawaid, Universitas Nurul Jadid, Probolinggo, Indonesia

Fariz Alnizar, Universitas Nahdlatul Ulama Indonesia, Jakarta, Indonesia

Pajar Hatma Indra Jaya, Universitas Islam Negeri Kalijaga, Yogyakarta, Indonesia

\section{Ilustrasi Cover}

'Menara Petunjuk', Shilfina Putri Widatama 
MUQODDIMA Jurnal Pemikiran dan Riset Sosiologi diterbitkan oleh Laboratorium Sosiologi, Departemen Sosiologi, Fakultas Sosial dan Humaniora, Universitas Nahdlatul Ulama Indonesia (UNUSIA) Jakarta. Jurnal ini terbit dua kali setahun, yaitu pada Juni dan Desember.

MUQODDIMA Jurnal Pemikiran dan Riset Sosiologi menyajikan karya-karya ilmiah di bidang sosiologi dan sosial humaniora. MUQODDIMA Jurnal Pemikiran dan Riset Sosiologi mengarahkan diri pada kajian sosial-keagamaan, budaya, politik-ekonomi, serta isuisu kemanusiaan dan lingkungan hidup baik yang dihasilkan dari penelitian lapangan maupun tinjauan kritis atas teori sosial. MUQODDIMA Jurnal Pemikiran dan Riset Sosiologi mengundang para akademisi dan peneliti di bidang sosial humaniora, khususnya sosiologi, serta para praktisi/aktivis sosial untuk mengirimkan karyanya.

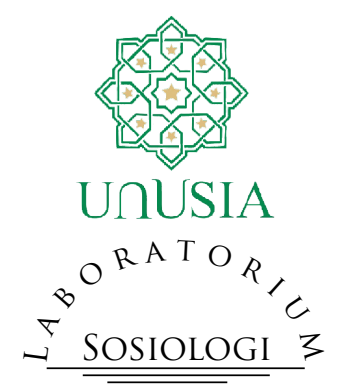

\author{
Alamat Editorial: \\ Kampus UNUSIA Jakarta \\ Jl. Taman Amir Hamzah No. 5 \\ Jakarta Pusat 10430 \\ Telp/Fax: (021) 3156864 / 3906501 \\ E-mail: muqaddima.jms@unusia.ac.id \\ Website: http://journal.unusia.ac.id/index.php/Muqoddima
}




\section{MUgODdima \\ JuRnal PEMikiran dan Riset Sosiologi}

Vol. 1 No. 2 Desember 2020

\section{DAFTAR IsI}

\section{Pengantar Editorial}

$i-x \mid$ Eneng Darol Afiah

Membaca Ulang 'Guncangan Besar' Francis Fukuyama

\section{Artikel}

113-132 | RaCHMAD K. Dwi SUSILO

Sosiologi Sebagai the Queen of Social Sciences: Sebuah Refleksi

133-144 Taufik Hidayadi \& Henny Saptatia Drajati Nugrahani Stereotip Warga Tionghoa dalam Geopolitik Hubungan Indonesia dengan Tiongkok

145-164 FARIZ ALNIZAR

Antara Iman dan Kenikmatan:

Konstruksi Gagasan Pascamodernisme Ariel Heryanto

165-180 Nana KristiaWAN

Dinamika Pengelolaan Sumber Daya Air di Situ Kemuning, Cimanggis Kabupaten Bogor

181-196 IndHAR WAHYU Wira HaRJo

Konsolidasi Demokrasi Melalui Liga Santri Nusantara

197-210 MoH. Faiz Maulana

Dangdut Koplo: Tubuh, Seksualitas, dan Arena Kekuasaan Perempuan

211-230 ELMY BONAFITA ZAHRO

Smoking Outcome Expectancy: Pengetahuan, Perilaku, dan Konsekuensi Merokok

TelaAh Buku

231-234 Muhammad Nurun Najib

Kembalinya Politik Identitas dan Identitas Nasional 


\title{
Smoking Outcome Expectancy: Pengetahuan, Perilaku, dan Konsekuensi Merokok
}

\author{
Elmy Bonafita Zahro \\ Program Studi Psikologi Universitas Nahdlatul Ulama \\ E-mail: elmy.bonafita@unusia.ac.id
}

\begin{abstract}
Abstrak
Penelitian ini bertujuan untuk melihat hubungan antara smoking outcome expectancy dan pengetahuan tentang bahaya merokok pada perokok dengan level kecanduan tinggi, sedang, dan rendah. Smoking outcome expectancy adalah konstruk untuk menjelaskan harapan yang diperoleh seseorang dari perilaku merokok. Penelitian ini melibatkan responden sebanyak 101 perokok dewasa muda. Smoking outcome expectancy diukur dengan menggunakan alat ukur SCQ-A (Smoking Consequences Questionnaire for Adults) yang disusun oleh Copeland dkk. (1995) yang diadaptasi oleh Jeffries dkk. (2004). Pengetahuan tentang bahaya merokok diukur dengan general knowledge of smoking yang disusun oleh Martini dan Sulistyowati (2005). Alat ukur untuk kategorisasi level ketergantungan merokok adalah FTND (Fagerström Test for Nicotine Dependence) yang dikembangkan oleh Fagerstro"m dkk. (1992). Penelitian ini menggunakan desain penelitian korelasional dengan metode pengolahan statistik pearson correlation. Terdapat dua hasil utama dari penelitian ini. Pertama, terdapat hubungan yang tidak signifikan antara positive smoking outcome expectancy dan pengetahuan tentang bahaya merokok pada perokok dewasa muda. Kedua, terdapat hubungan positif yang signifikan antara negative smoking outcome expectancy dan pengetahuan tentang bahaya merokok pada perokok dewasa muda. Hal ini dimungkinkan pengetahuan tentang bahaya merokok bukan merupakan prediktor utama bagi perilaku merokok dan smoking outcome expectancy. Bagi orang yang merokok dengan level ketergantungan tinggi, pengetahuan sudah tidak mempengaruhi perilakunya. Perilaku merokok diharapkan bisa menjadi coping stress atau mekanisme fisiologis yang dibutuhkan tubuh.
\end{abstract}

Kata Kunci: perilaku merokok, smoking outcome expectancy, pengetahuan tentang bahaya merokok, dewasa-muda 


\begin{abstract}
This study aims to see the relationship between smoking outcome expectancy and knowled ge about the dangers of smoking in smokers with high, moderate, and low levels of addiction. Smoking outcome expectancy is a construct to explain the expectations a person gets from smoking behavior. This study involved 101 young adult smokers as respondents. Smoking outcome expectancy is measured by the SCQ-A (Smoking Consequences Questionnaire for Adults) measuring instrument compiled by Copeland et al. (1995) adapted by Jeffries et al. (2004). Knowledge about the dangers of smoking is measured by general knowledge of smoking compiled by Martini and Sulistyowati (2005). The measuring tool for categorizing the level of smoking dependence is the FTND (Fagerström Test for Nicotine Dependence) developed by Fagerstro“m et al. (1992). This study uses a correlational research design with the pearson correlation statistical processing method. There are two main results from this study. First, there is a non-significant relationship between positive smoking outcome expectancy and knowledge about the dangers of smoking in young adult smokers. Second, there is a significant relationship between the negative smoking outcome expectancy and knowledge about the dangers of smoking in young adult smokers. It is possible that knowledge about the dangers of smoking is not a major predictor of smoking behavior and the smoking outcome expectancy. For people who smoke with a high level of dependence, knowledge does not affect their behavior. Smoking behavior is expected to be a coping stress or physiological mechanism that the body needs.
\end{abstract}

Keywords: smoking behavior, smoking outcome expectancy, knowledge about the danger of smoking, young adult

\title{
Pendahuluan
}

Perilaku merokok merupakan salah satu isu kesehatan, baik fisik, psikis, maupun sosial yang menjadi perhatian dunia, begitu juga di Indonesia. Terdapat beberapa data yang mendukung isu tersebut. Misalnya, berdasarkan data WHO tahun 2008, Indonesia merupakan negara perokok ketiga terbesar setelah Cina dan India dengan jumlah perokok sekitar 65 juta dari total 225 juta jiwa $(28.9 \%$ per penduduk atau sekitar 225 miliar batang per tahun) (http:/ /www.kompas. com). Hampir 30\% penduduk Indonesia dari segala rentang usia merupakan perokok aktif. Pertumbuhan konsumsi rokok di Indonesia pada periode 2000-2008 mencapai $0.9 \%$ per tahun (http://cancerhelps.co.id). Padahal, pemerintah telah menetapkan kebijakan dengan memberikan peringatan keras tentang dampak dan bahaya merokok pada setiap kemasan rokok yaitu "merokok dapat menyebabkan kanker, serangan jantung, impotensi dan gangguan kehamilan dan janin". Selain itu, pemerintah juga memberikan larangan untuk memunculkan gambar atau penggunaan rokok pada iklan rokok. Akan tetapi, tingkat konsumsi rokok di Indonesia makin hari makin meningkat. 
Penelitian Grinder (1978) menunjukkan bahwa kampanye untuk meminta masyarakat berhenti merokok melalui adanya larangan iklan rokok di televisi cukup efektif. Sarafino (1990) memberikan bukti penurunan jumlah orang merokok di negara maju, yaitu 53\% laki-laki dewasa dan 34\% perempuan dewasa berkurang menjadi 30\% laki-laki dewasa dan 26\% perempuan dewasa. Di sisi lain, Rice (1990) menyebutkan bahwa dengan adanya iklan rokok, perilaku merokok diidentifikasikan dengan maskulinitas, kebebasan, berjiwa muda, kecerdasan, dan good living. Secara umum, iklan televisi memberikan dampak yang besar terhadap lifestyle merokok di masyarakat. Iklan rokok di Indonesia kebanyakan menampilkan laki-laki yang maskulin dan berani menghadapi tantangan serta perempuan yang seksi dan menarik. Dengan adanya image perilaku merokok yang seperti digambarkan di iklan semakin membuat seseorang tertarik untuk merokok dan menguatkan perilakunya.

Perilaku merokok memberikan dampak negatif pada tubuh manusia. Nikotin sebagai kandungan dari tembakau yang menjadi bahan dasar pembuatan rokok merupakan salah satu zat adiktif yang pemakaiannya juga bisa disamakan bahayanya dengan narkotika dan zat psikotropika lainnya (Kaplan, Sallis, dan Patterson 1993). Berdasarkan data dari Badan Narkotika Nasional (BNN) menyebutkan bahwa pemakaian rokok dan alkohol terutama pada remaja harus menjadi bagian dari upaya pencegahan karena rokok dan alkohol sering menjadi pintu masuk penyalahgunaan NAPZA (narkotika, psikotropika, dan zat adiktif lainnya) lain yang lebih berbahaya. Zat adiktif tersebut bila masuk ke dalam tubuh manusia akan mempengaruhi tubuh terutama otak atau susunan saraf pusat, sehingga menyebabkan gangguan kesehatan fisik, psikis, dan fungsi sosialnya karena terjadi kebiasaan, ketagihan (adiksi) serta ketergantungan (dependency) (http://bnn.go.id).

Kecenderungan berperilaku tertentu memungkinkan adanya harapan atau konsekuensi dari perilakunya atau outcome expectancy. Misalnya, seseorang yang merokok agar dapat berkonsentrasi dan fokus terhadap pekerjaanya. Ada juga orang yang merokok untuk mengurangi kadar emosi positif, baik marah, sedih, kesal, dan sebagainya. Perempuan merokok sebagai sarana diet (Kenneth dkk. 1993) karena kandungan nikotin pada rokok menekan rasa lapar atau mengalihkan keinginan "ngemil" pada rokok. Outcome expectancy merujuk kepada kemampuan individu untuk memanfaatkan informasi yang tersimpan dalam memori untuk mengarahkan dan mengatur perilaku yang akan datang (Reig-Ferrer dan CepedaBenito 2007). Expectancy juga diartikan Goldman (2002) sebagai keyakinan tentang kemungkinan konsekuensi dari keterlibatan dalam suatu perilaku. Donovan (1988) menambahkan bahwa outcome expectancy memainkan peran utama dalam menentukan penggunaan narkoba secara legal dan ilegal termasuk merokok. Begitu juga dengan merokok yang disebut juga dengan smoking outcome expectancy (Brandon dan Baker 1991).

Penggunaan segala sesuatu yang berlebihan dapat menimbulkan dampak yang tidak baik. Merokok yang berlebihan juga dapat mengarah pada ketergantungan (dependency) dan kecanduan (addiction). Kecanduan merokok 
berdampak tidak hanya pada diri si pecandu sendiri namun juga mempengaruhi kehidupan sosialnya dengan orang-orang di sekitarnya. Dampak bagi diri sendiri terdiri dari dua hal yaitu dampak fisiologis dan psikologis. Secara fisiologis, rokok yang berlebihan dan mengarah pada perilaku kecanduan dapat mengakibatkan berbagai macam penyakit, seperti kerusakan paru-paru, penurunan fertilitas, penyakit kardiovaskular, peningkatan tekanan darah, gangguan nafsu seksual, impotensi, sampai pada kematian (Sitepoe 2001). Selain itu, kecanduan merokok dan minuman keras merupakan gerbang ke arah narkoba (http:/ / bnn.go.id) yang mana bahaya pada kesehatan lebih parah lagi daripada rokok. Dampak psikologis yang kemungkinan muncul adalah kecemasan ketika akses terhadap rokok tidak ada atau berkurang, kesulitan konsentrasi dan tidak merasa tenang dan nyaman ketika tidak merokok selama jangka waktu tertentu. Bagi seseorang yang berada pada rentang SSE rendah, kecanduan merokok mengakibatkan pengeluaran keuangannya besar atau masalah ekonomi. Hal ini akan menambah beban hidup yang dapat menimbulkan stress. Gangguan yang ditimbulkan psikologis seseorang juga akan mempengaruhi kualitas hubungan interpersonal dengan orang tua, pasangan, teman, rekan kerja, dan juga siapapun yang berada di sekitarnya. Misalnya, seorang suami yang merokok akan membuat istri dan anaknya menjadi perokok pasif.

Dari data yang telah dijelaskan sebelumnya muncul pertanyaan mengenai seberapa besar pengetahuan para perokok aktif terhadap bahaya dari perilaku merokok, baik bagi dirinya sendiri maupun bagi orang lain yang berada di sekitarnya. Apakah pengetahuan tentang bahaya merokok merupakan faktor yang kuat memprediksi konsekuensi harapan dari perilaku merokok seseorang ataukah sebaliknya. Misalnya, seorang ayah yang memiliki anak dan istri dan tetap saja merokok ketika berada di sekitar keluarganya apakah ayah tersebut tidak mengetahui dampak asap rokok terhadap kesehatan dirinya, anak, dan istrinya ataukah cenderung mengabaikan pengetahuan tentang bahaya dari perilaku merokok karena ketergantungannya terhadap rokok yang tidak dapat ditahan.

Pengetahuan tentang bahaya merokok berasal dari lingkungan sekitarnya, seperti iklan, buku atau bahan bacaan, teman-teman, dan apapun yang berasal dari lingkungan sekitarnya yang kemudian diinternalisasi dalam ranah kognitifnya (Pollay 2000). Pengetahuan tentang bahaya merokok terdiri dari pengetahuan tentang pengaruh asap rokok secara langsung terhadap diri perokok, pengetahuan tentang pengaruh asap rokok terhadap perokok pasif, pengetahuan tentang intensitas dan durasi merokok bagi perokok, dan pengetahuan tentang keyakinan kemudahan dan manfaat dari berhenti merokok (Martini dan Sulistyowati 2005).

Smoking outcome expectancy dan pengetahuan tentang bahaya merokok merupakan dua faktor yang saling mempengaruhi kecenderungan seseorang untuk berperilaku merokok. Hubungan antara kedua faktor tersebut diasumsikan penting untuk melihat apakah kedua faktor tersebut dapat dijadikan indikasi individu dalam memutuskan perilaku merokoknya yang mengarah pada kecanduan merokok. Dengan demikian, penelitian tentang hubungan antara positive smoking outcome expectancy, negative smoking outcome expectancy, dengan pengetahuan 
tentang bahaya merokok pada setiap level kecanduan perokok dianggap penting untuk dilakukan. Penelitian ini dapat digunakan untuk mengetahui gambaran positive smoking outcome expectancy dan negative smoking outcome expectancy pada dewasa muda yang merokok dikaitkan dengan pengetahuannya tentang bahaya merokok.

Bandura (1986) membagi expectancy menjadi dua faktor, yaitu affective individual behavioral dan affective outcome (self-efficacy dan outcome expectancy). Outcome expectancy diartikan sebagai kepercayaan individu bahwa pencapaian tugas akan mengarahkan pada suatu hasil tertentu. Fungsi dari outcome expectancy adalah untuk menyiapkan individu menghadapi situasi yang akan datang berdasarkan pada situasi yang telah dilaluinya di masa lalu (Bandura 1999). Goldman dkk. (1999) mendefinisikan outcome expectancy sebagai hubungan antara stimulus, respon, dan hasil dari respon, dan hubungan itu merupakan pemikiran yang mempengaruhi tingkah laku yang akan datang. Jadi, expectancy adalah kepercayaan tentang konsekuensi yang memiliki kemungkinan untuk mempengaruhi perilaku (Goldman 2002). Conner dan Norman (1996) menambahkan bahwa outcome expectancy berkaitan dengan persepsi seseorang tentang konsekuensi yang mungkin terjadi oleh tindakan yang dilakukannya.

Dari beberapa pengertian yang telah dijelaskan sebelumnya maka pengertian dari smoking outcome expectancy adalah kepercayaan individu tentang konsekuensi yang mungkin terjadi di masa yang akan datang dari perilaku merokok yang telah dilakukannya. Jeffries dkk. (2004) membagi smoking outcome expectancy yang diukur dengan Smoking Consequences Quesioner-Adult (SCQ-A) ke dalam sembilan dimensi, yaitu enam dimensi mencakup positive smoking outcome expectancy dan tiga dimensi negative smoking outcome expectancy (lihat Bagan 1).

Positive outcome expectancy memiliki kecenderungan penggunaan rokok berkelanjutan dan memungkinkan adanya keinginan untuk menggunakannya lagi, sedangkan negative outcome expectancy menunjukkan motivasi menahan diri untuk menghindari penggunaan rokok. Enam bagian yang termasuk dalam positive smoking outcome expectancy, antara lain negative affect reduction, stimulationstate enhancement, taste-sensorimotor manipulation, social facilitation, weight control, dan boredom reduction. Sedangkan, tiga bagian lain yang termasuk dalam negative smoking outcome expectancy adalah health risk, negative physical feelings, dan negative social impression. Berikut ini adalah penjelasan tentang setiap dimensi smoking outcome expectancy, yaitu:

Enam dimensi yang dikelompokkan dalam positive smoking outcome expectancy, antara lain:

1. Negative affect reduction atau mengurangi emosi negatif, konsekuensi positif yang diharapkan dapat menurunkan perasaan atau emosi negatif yang dirasakan.

2. Stimulation-state enhancement atau menstimulasi diri, konsekuensi positif yang diharapkan dapat menstimulasi diri untuk menaikan keadaan diri.

3. Taste-sensorimotor manipulation atau manipulasi sensorimotor, konsekuensi positif yang diharapkan berupa sensasi rasa yang menyenangkan pada diri 
sendiri.

4. Social facilitation atau pergaulan sosial, konsekuensi positif yang diharapkan muncul dari lingkungan sosialnya dan berasal dari perilaku merokoknya.

5. Weight control atau mengontol berat badan, konsekuensi positif yang diharapkan berupa kemampuan untuk mengotrol rasa lapar dan berat badan sebagai akibat dari perilaku merokok.

6. Boredom reduction atau mengurangi kebosanan, konseuensi positif yang diharapkan berupa berkurangnya kebosanan.

Sedangkan, tiga dimensi yang termasuk dalam negative smoking outcome expectancy, antara lain:

1. Health risk atau resiko kesehatan, konsekuensi negatif berupa resiko kesehatan fisik yang bisa terjadi.

2. Negative physical feelings atau perasan negatif pada fisik, konsekuensi negatif berupa perasaan ketidaknyamaan atau rasa sakit fisik yang mungkin terjadi akibat perilaku merokok.

3. Negative social impression atau pandangan negatif lingkungan sosial, konsekuensi negatif berupa kesan negatif yang diberikan oleh lingkungan sosialnya.

\section{Bagan 1}

\section{Dimensi Smoking Outcome Expectancy}

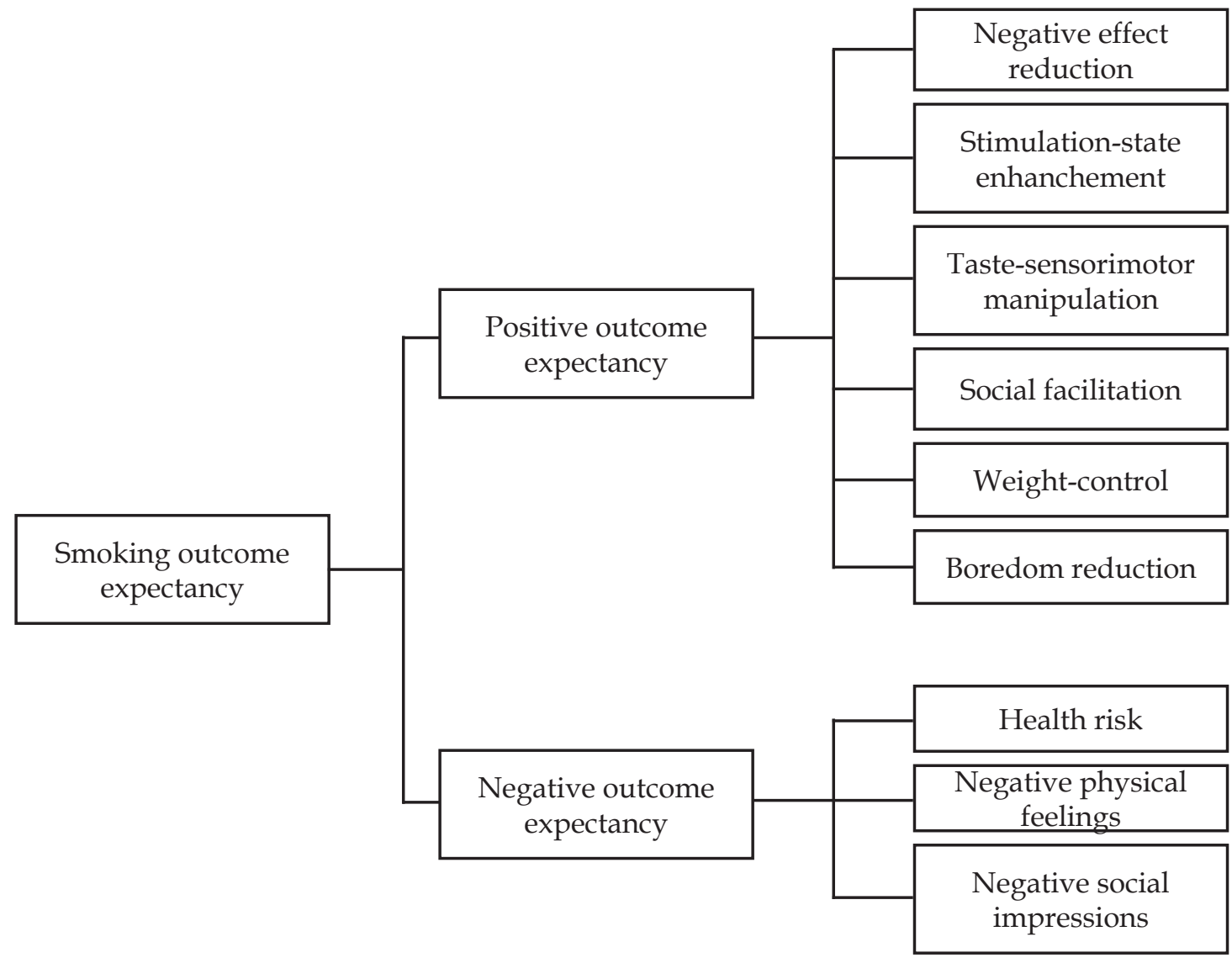

Selain itu, terdapat faktor-faktor yang mempengaruhi perilaku merokok 
adalah biologis, psikologis, dan sosial. Pertama, faktor biologis terlihat dari adanya kandungan nikotin dalam rokok yang dapat menyebabkan ketergantungan fisik pada orang-orang yang merokok. Kedua, faktor psikologis dari dalam diri seperti harga diri dan kebutuhan untuk diakui dari perilaku merokoknya, habit, kebutuhan untuk memunculkan reaksi emosi positif, dan kebutuhan untuk menurunkan emosi negatif (Oskamp 1984). Ketiga, faktor sosial dari lingkungan perokok itu sendiri seperti, iklan rokok, proses imitasi terhadap orang-orang sekitarnya, ayah, ibu, kakak, teman, dan tekanan kelompok sosial di sekitarnya (Rice 1990).

Salah satu aspek yang hendak diteliti ada dari faktor kognitif atau pengetahuan seseorang tentang bahaya merokok. Martini dan Sulistyowati (2005) mengelompokkan pengetahuan umum tentang pengaruh negatif atau bahaya merokok terhadap kesehatan, antara lain: (1) pengetahuan tentang pengaruh asap rokok secara langsung terhadap diri perokok; (2) pengetahuan tentang pengaruh asap rokok terhadap perokok pasif; (3) pengetahuan tentang intensitas dan durasi merokok bagi perokok; dan (4) pengetahuan tentang keyakinan kemudahan dan manfaat dari berhenti merokok.

Sedangkan perilaku merokok tersendiri ketika sudah mengarah pada ketergantungan dari ditunjukkan dari kriteria diagnostiknya. Menurut DSM-IV TR (American Psychyatric Association 2000), terdapat beberapa kriteria apabila seseorang mengalami ketergantungan nikotin, antara lain toleransi (kebutuhan dosis rokok naik untuk memperoleh hasil yang diinginkan), discontinue symptom (muncul kembali keinginan merokok setelah periode tidak menggunakan atau abstinence), adanya keinginan merokok dan ketidakmampuan mengurangi konsumsinya, banyak waktu yang dihabiskan untuk merokok dan untuk mendapatkan rokok, meninggalkan dan mengurangi kegiatan-kegiatan lain karena merokok (kegiatan sosial, profesional, dan istirahat atau santai), dan terus menerus merokok meskipun terdapat konsekuensi dan risiko kesehatan.

Lalu untuk dapat merangkum dinamika perilaku ketergantungan merokok dari aspek individu (misalnya kognitif dan efficacy), lingkungan sosial, dan perilaku merokoknya, peneliti menggunakan kerangka berpikir teori belajar sosial Albert Bandura. Teori belajar sosial menjelaskan dan memprediksi perubahan tingkah laku dari dua fenomena penting. Pertama, Bandura (1986) berpendapat bahwa manusia dapat berpikir dan mengatur tingkah lakunya sendiri sehingga mereka bukan semata-mata menjadi objek pengaruh lingkungan. Sifat kausal tidak hanya dimiliki oleh lingkungan melainkan terjadi pada individu dan lingkungan. Kedua, Bandura mengatakan banyak aspek fungsi kepribadian yang melibatkan interaksi satu individu dengan individu lainnya. Dampaknya, teori kepribadian yang memadai harus memperhitungkan konteks sosial dimana tingkah laku tertentu diperoleh dan dipelihara. Hal ini sejalan untuk memahami proses penggunaan rokok dan perilaku kecanduan merokok yang melibatkan faktor sosial dan individu yang bersangkutan. 


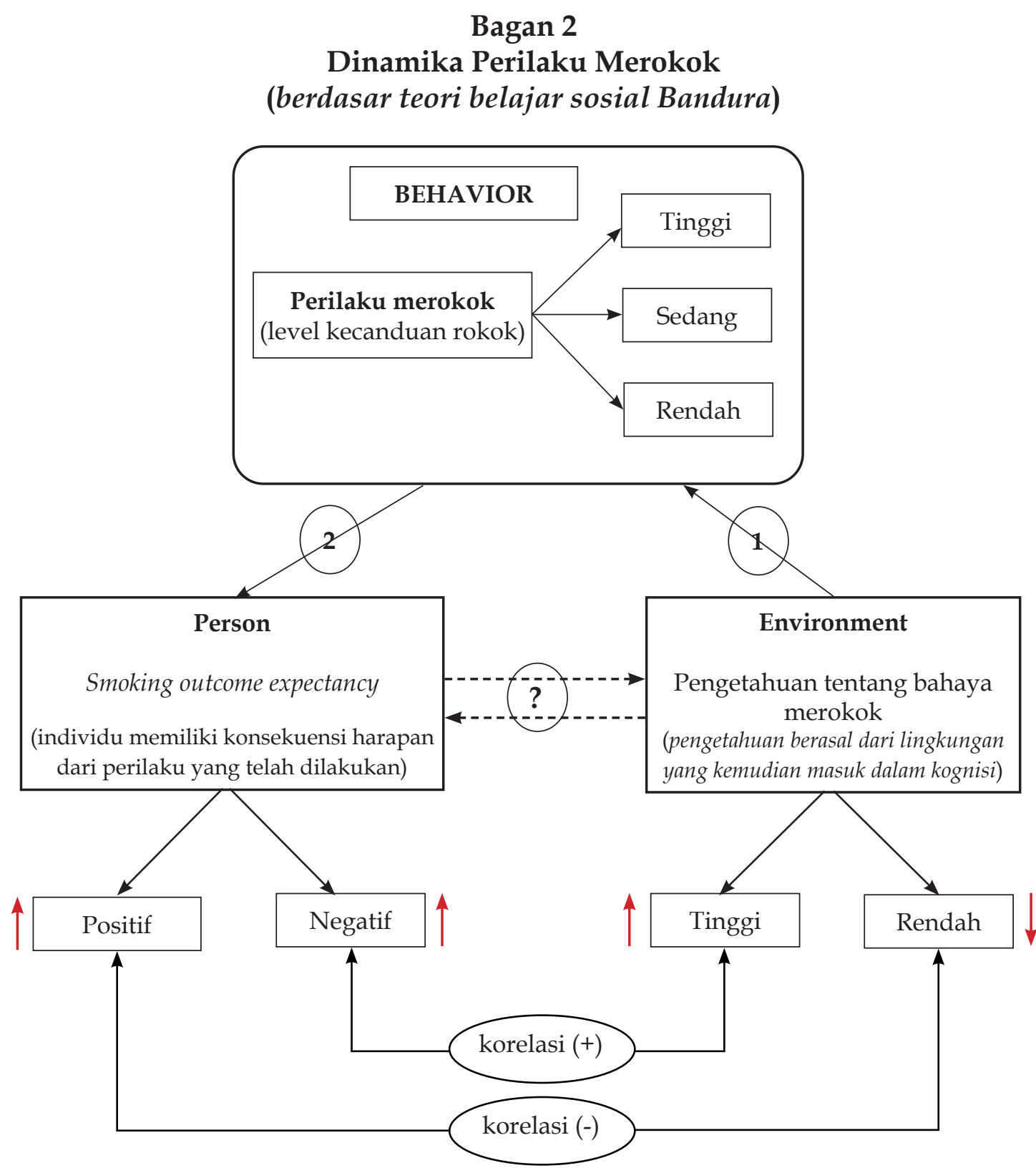

Bagan di atas ini mengadopsi teori belajar sosial Bandura. Pengetahuan tentang bahaya merokok merupakan salah satu faktor penyebab dari perilaku merokok yang diasumsikan berasal dari lingkungan sekitar individu. Setiap orang yang merokok sebagian besar telah memiliki pengetahuan tentang bahaya merokok itu seperti apa (misalnya, peringatan bahaya merokok yang tercantum pada bungkus rokok "merokok dapat menyebabkan kanker, serangan jantung, impotensi dan gangguan kehamilan dan janin“). Perilaku merokok merupakan tingkah laku yang dilakukan individu dan memiliki tahapan atau level kecanduan, yaitu rendah, sedang, sampai dengan tinggi. Setiap orang berbeda-beda tahapan kecanduan merokoknya tergantung dengan faktor dalam diri (seperti, coping stress) maupun luar dirinya (seperti, modeling). Perilaku merokok juga memberikan konsekuensi atau smoking outcome expectancy terhadap diri individu.

Smoking outcome expectancy merupakan kepercayaan seseorang tentang konsekuensi yang mungkin terjadi di masa yang akan datang dari perilaku 
merokok yang telah dilakukannya (Jeffries dkk. 2004). Terdapat dua konsekuensi dari perilaku merokok, yaitu konsekuensi positif atau positive smoking outcome expectancy (kecenderungan merokok berkelanjutan dan memungkinkan adanya keinginan untuk menggunakannya lagi) dan konsekuensi negatif atau negative smoking outcome expectancy (kecenderungan menahan diri untuk menghindari merokok). Pada penelitian ini, peneliti melihat hubungan antara smoking outcome expectancy dan pengetahuan tentang bahaya merokok. Secara spesifik, smoking outcome expectancy tidak bisa dilihat sebagai satu variabel kesatuan karena konsekuensi yang muncul dari perilaku merokok terdiri dari konsekuensi positif dan negatif yang masing-masing saling berdiri sendiri. Dengan demikian, peneliti membuat asumsi dengan mengkorelasikan antara positive smoking outcome expectancy, negative smoking outcome expectancy, dan pengetahuan tentang bahaya merokok.

Pada penelitian ini, pertama peneliti melihat gambaran pengetahuan tentang bahaya merokok pada perokok yang kecanduan merokok level tinggi, sedang, dan rendah. Kedua, peneliti melihat gambaran positive smoking outcome expectancy dan negative smoking outcome expectancy pada perokok yang kecanduan merokok level tinggi, sedang, dan rendah. Selanjutnya, permasalah utama yang ingin dilihat peneliti adalah dua hubungan pada variabel smoking outcome expectancy dan pengetahuan tentang bahaya merokok. Pertama, hubungan antara positive smoking outcome expectancy dan pengetahuan tentang bahaya merokok. Peneliti sudah memiliki asumsi tentang arah korelasi antarvariabel itu. Semakin tinggi konsekuensi positif yang diharapkan muncul dari perilaku merokok seseorang maka semakin rendah pengetahuannya tentang bahaya merokok atau dengan kata lain hubungan antarvariabel tersebut bersifat negatif (korelasi negatif). Ketika seseorang memiliki harapan konsekuensi yang positif dari perilaku merokok dimungkinkan pengehuan orang itu tentang bahaya merokok rendah, hubungan ini akan memperkuat perilaku merokoknya. Asumsi ini dijadikan hipotesis penelitian, yaitu terdapat hubungan negatif antara positive smoking outcome expectancy dan pengetahuan tentang bahaya merokok pada perokok dewasa muda. Hubungan kedua yang dilihat oleh peneliti adalah hubungan antara negative smoking outcome expectancy dan pengetahuan tentang bahaya merokok. Peneliti mengasumsikan bahwa semakin tinggi konsekuensi negatif yang muncul dari perilaku merokok seseorang maka semakin tinggi pula pengetahuannya tentang bahaya merokok atau dengan kata lain hubungan antarvariabel tersebut bersifat positif (korelasi positif). Asumsi ini dijadikan hipotesis kedua penelitian, yaitu terdapat hubungan positif antara negative smoking outcome expectancy dan pengetahuan tentang bahaya merokok pada perokok dewasa muda.

\section{Metode}

Responden penelitian ini adalah dewasa muda yang berada pada rentang usia 20 sampai dengan 40 tahun (Papalia dkk. 2009). Berdasarkan analisis faktor penelitian Copeland dkk. (1995), disarankan untuk mengambil responden perokok dewasa karena dianggap memiliki jumlah expectancy yang lebih kuat. 
Responden penelitian juga perokok aktif yang tergolong perokok rutin (regular smoker) yaitu orang yang merokok dalam hitungan minggu (per minggu) atau lebih sering lagi, yaitu per hari. Besar responden yang diperoleh dalam penelitian ini sebesar 101 respon yang terdiri dari 62 responden dengan level ketergantungan tinggi, 25 responden level ketergantungan sedang, dan 14 responden dengan level ketergantungan rendah. Proses pengambilan data diperoleh dengan cara menyebarkan kuesioner pada perokok yang kriterianya sesuai dengan yang telah dijelaskan sebelumnya baik melalui online maupun offline.

Terdapat tiga variabel dan tiga alat ukur dalam penelitian ini. Pertama, smoking outcome expectancy diperoleh dari skor total dari nilai rata-rata setiap dimensi dari kuesioner SCQ-A (Jeffries dkk. 2004). Kuesioner SCQ-A terdiri dari 30 item, dengan 9 dimensi yang dibagi dalam 2 kriteria, yaitu 6 dimensi positive smoking outcome expectancy dan 3 dimensi negative smoking outcome expectancy dengan menggunakan skala likert 1 (sangat tidak sesuai) sampai dengan 10 (sangat sesuai). Kedua, pengetahuan terhadap bahaya merokok didapat dari skor total kuesioner general knowledge of smoking (Martini dan Sulistyowati 2005) yang terdiri dari 20 item dengan 3 pilihan jawaban, yaitu benar, salah, dan tidak tahu. Ketiga, kecanduan merokok diperoleh dari skor total kuesioner FTND (Fagerstro“m dkk. 1992) yang terdiri dari 6 item dengan skor masing-masing yang telah ditetapkan oleh Fagerstro"m. Kategorisasi level kecanduan merokok terdiri dari level rendah (skor FTND = 0-3 poin), level sedang (skor FTND = 4-6 poin), dan level tinggi (skor FTND $\geq 7$ poin).

Setelah seluruh data terkumpul, dilakukan pengolahan data dengan menggunakan SPSS 16.0. Teknik statistik yang digunakan adalah compare means untuk melihat gambaran positive smoking outcome expectancy, negative smoking outcome expectancy, dan pengetahuan tentang bahaya merokok pada setiap level ketergantungan; pearson correlation untuk melihat hubungan antara smoking outcome expectancy dan pengetahuan tentang bahaya merokok; dan independent sample t-test untuk melihat perbedaan positive smoking outcome expectancy, negative smoking outcome expectancy, dan pengetahuan bahaya merokok pada dewasa muda dengan level ketergantungan tinggi dan level rendah.

\section{Temuan dan Analisis}

Data hasil penelitian yang telah dilakukan berdasarkan hasil pengisian kuesioner yang diberikan pada responden penelitian, kemudian kuesioner tersebut diolah dengan menggunakan program SPSS 16.0 for windows. Perhitungan yang digunakan dalam penelitian dalam penelitian ini terdiri atas perhitungan pearson product moment $\left(\mathrm{r}^{2}\right)$.

Berdasarkan hasil korelasi antara skor positive smoking outcome expectancy dan pengetahuan tentang bahaya merokok didapatkan koefisien korelasi $\left(\mathrm{r}^{2}\right)$ sebesar 0,029 tidak signifikan. Hasil ini menunjukkan adanya hubungan positif yang tidak signifikan yang menunjukkan bahwa kenaikan skor pada variabel positive smoking outcome expectancy tidak diikuti oleh kenaikan skor pada variabel 
pengetahuan tentang bahaya merokok. Hal ini berarti, hipotesis alternatif yang menyatakan bahwa terdapat hubungan negatif antara positive smoking outcome expectancy dan pengetahuan tentang bahaya merokok ditolak dan hipotesis null diterima.

Tabel 1

Korelasi Antar Variabel

\begin{tabular}{|l|c|c|}
\hline \multicolumn{1}{|c|}{ Korelasi Antarvariabel } & $\begin{array}{c}\text { Koefisien } \\
\text { korelasi }\left(\mathbf{r}^{2}\right)\end{array}$ & Signifikansi \\
\hline $\begin{array}{l}\text { Positive smoking outcome expectancy * } \\
\text { pengetahuan tentang bahaya merokok }\end{array}$ & 0.029 & 0.388 \\
\hline $\begin{array}{l}\text { Negative smoking outcome expectancy * } \\
\text { pengetahuan tentang bahaya merokok }\end{array}$ & $0.388^{* *}$ & 0.000 \\
\hline
\end{tabular}

Keterangan ** korelasi siginifikan pada level of significant 0.01 (1-tailed)

Berdasarkan hasil korelasi antara skor negative smoking outcome expectancy dan pengetahuan tentang bahaya merokok didapatkan koefisien korelasi $\left(\mathrm{r}^{2}\right)$ sebesar 0,388 signifikan pada ( $\mathrm{p}>0.01$ ). Hasil ini menunjukkan adanya hubungan positif yang signifikan yang menunjukkan bahwa kenaikan skor pada variabel negative smoking outcome expectancy diikuti oleh kenaikan skor pada variabel pengetahuan tentang bahaya merokok. Hal ini berarti, hipotesis alternatif yang menyatakan bahwa terdapat hubungan positif antara negative smoking outcome expectancy dan pengetahuan tentang bahaya merokok, diterima dan hipotesis null ditolak.

Berdasarkan perbandingan nilai mean positive smoking outcome expectancy dan negative smoking outcome expectancy, secara kesuluruhan didapat hasil bahwa skor rata-rata positive smoking outcome expectancy lebih tinggi ( $\mathrm{M}=6.64$ dari nilai minimum 1.22 sampai dengan nilai maksimum 9.6) dibandingkan dengan negative smoking outcome expectancy $(\mathrm{M}=5.82$ dari nilai minimum 1.75 sampai dengan nilai maksimum 8.78) (lihat tabel 2).

Tabel 2

Perbandingan Skor Mean Positive Smoking Outcome Expectancy dan Negative Smoking Outcome Expectancy

\begin{tabular}{|c|c|c|c|}
\hline \multirow{2}{*}{$\begin{array}{c}\text { Level Kecanduan } \\
\text { Merokok }\end{array}$} & \multicolumn{2}{|c|}{ Smoking Outcome Expectancy } & $\begin{array}{c}\text { Jumlah } \\
\text { Responden } \\
\text { (orang) }\end{array}$ \\
\cline { 2 - 3 } & $\begin{array}{c}\text { Skor Mean Positive } \\
\text { Smoking Outcome Ex- } \\
\text { pectancy }\end{array}$ & $\begin{array}{c}\text { Skor Mean Negative } \\
\text { Smoking Outcome Ex- } \\
\text { pectancy }\end{array}$ & 62 \\
\hline Rendah & 6.52 & 6.12 & 25 \\
\hline Sedang & 6.63 & 5.56 & 14 \\
\hline Tinggi & 7.17 & 4.98 & $\mathbf{1 0 1}$ \\
\hline Total & $\mathbf{6 . 6 4}$ & $\mathbf{5 . 8 2}$ & 1 \\
\hline
\end{tabular}

Skor rata-rata positive smoking outcome expectancy pada perokok dewasa muda yang kecanduan merokok pada level tinggi adalah paling tinggi $(\mathrm{M}=7.17)$ dibandingkan dengan skor rata-rata pada perokok dewasa muda yang kecanduan merokok pada level sedang $(M=6.63)$ dan level rendah $(M=6.52)$. Dengan demikian, 
berdasarkan urutan positive smoking outcome expectancy tertinggi sampai dengan terendah adalah perokok aktif dewasa muda yang kecanduan merokok pada level tinggi, level sedang, dan level rendah. Sedangkan, skor rata-rata negative smoking outcome expectancy pada perokok dewasa muda yang kecanduan merokok pada level tinggi adalah paling rendah $(\mathrm{M}=4.98)$ dibandingkan dengan skor rata-rata pada perokok dewasa muda yang kecanduan merokok pada level sedang $(M=5.56)$ dan level rendah $(\mathrm{M}=6.12)$. Dengan demikian, berdasarkan urutan negative smoking outcome expectancy terendah sampai dengan tertinggi adalah perokok dewasa muda yang kecanduan merokok pada level tinggi, level sedang, dan level rendah.

Perbandingan nilai mean dimensi positive smoking outcome expectancy, secara keseluruhan didapat hasil bahwa dimensi Tension-Sensorimotor Manipulation (TSM) memiliki skor rata-rata paling tinggi (M=7.71) dan dimensi Weight Control (WC) memiliki skor rata-rata paling rendah $(\mathrm{M}=5.17)$. Secara berurutan dari skor rata-rata tertinggi dimensi positive smoking outcome expectancy sampai dengan skor rata-rata terendah adalah Tension-Sensorimotor Manipulation (TSM) (M=7.71), Boredom Reduction (BR) (M=7.35), Negative Affect Reduction (NAR) (M=6.83), Social Facilitation (SF) $(\mathrm{M}=6.40)$, Stimulation-State Enhancement (SSE) $(\mathrm{M}=6.32)$, dan Weight Control (WC) (M=5.17). Perbandingan nilai mean dimensi negative smoking outcome expectancy, secara keseluruhan didapat hasil bahwa dimensi Health Risk (HR) memiliki skor rata-rata tertinggi $(\mathrm{M}=7.19)$ dan dimensi Negative Social Impression (NSI) memiliki skor rata-rata terendah $(\mathrm{M}=4.82)$ (lihat tabel 3) Secara berurutan dari dari skor rata-rata tertinggi dimensi negative smoking outcome expectancy sampai dengan skor rata-rata terendah adalah Health Risk (HR) (M=7.19), Negative Physical Feelings (NPF) (M=5.47), dan Negative Social Impression (NSI) (M=4.82) (lihat Tabel 3 di halaman berikut).

Perbandingan nilai mean dimensi positive smoking outcome expectancy, secara keseluruhan didapat hasil bahwa dimensi Tension-Sensorimotor Manipulation (TSM) memiliki skor rata-rata paling tinggi $(\mathrm{M}=7.71)$ dan dimensi Weight Control (WC) memiliki skor rata-rata paling rendah $(\mathrm{M}=5.17)$. Secara berurutan dari skor rata-rata tertinggi dimensi positive smoking outcome expectancy sampai dengan skor rata-rata terendah adalah Tension-Sensorimotor Manipulation (TSM) (M=7.71), Boredom Reduction (BR) (M=7.35), Negative Affect Reduction (NAR) (M=6.83), Social Facilitation (SF) $(\mathrm{M}=6.40)$, Stimulation-State Enhancement (SSE) $(\mathrm{M}=6.32)$, dan Weight Control (WC) (M=5.17). Perbandingan nilai mean dimensi negative smoking outcome expectancy, secara keseluruhan didapat hasil bahwa dimensi Health Risk (HR) memiliki skor rata-rata tertinggi $(\mathrm{M}=7.19)$ dan dimensi Negative Social Impression (NSI) memiliki skor rata-rata terendah $(\mathrm{M}=4.82)$ (lihat tabel 3) Secara berurutan dari dari skor rata-rata tertinggi dimensi negative smoking outcome expectancy sampai dengan skor rata-rata terendah adalah Health Risk (HR) (M=7.19), Negative Physical Feelings (NPF) (M=5.47), dan Negative Social Impression (NSI) (M=4.82). 


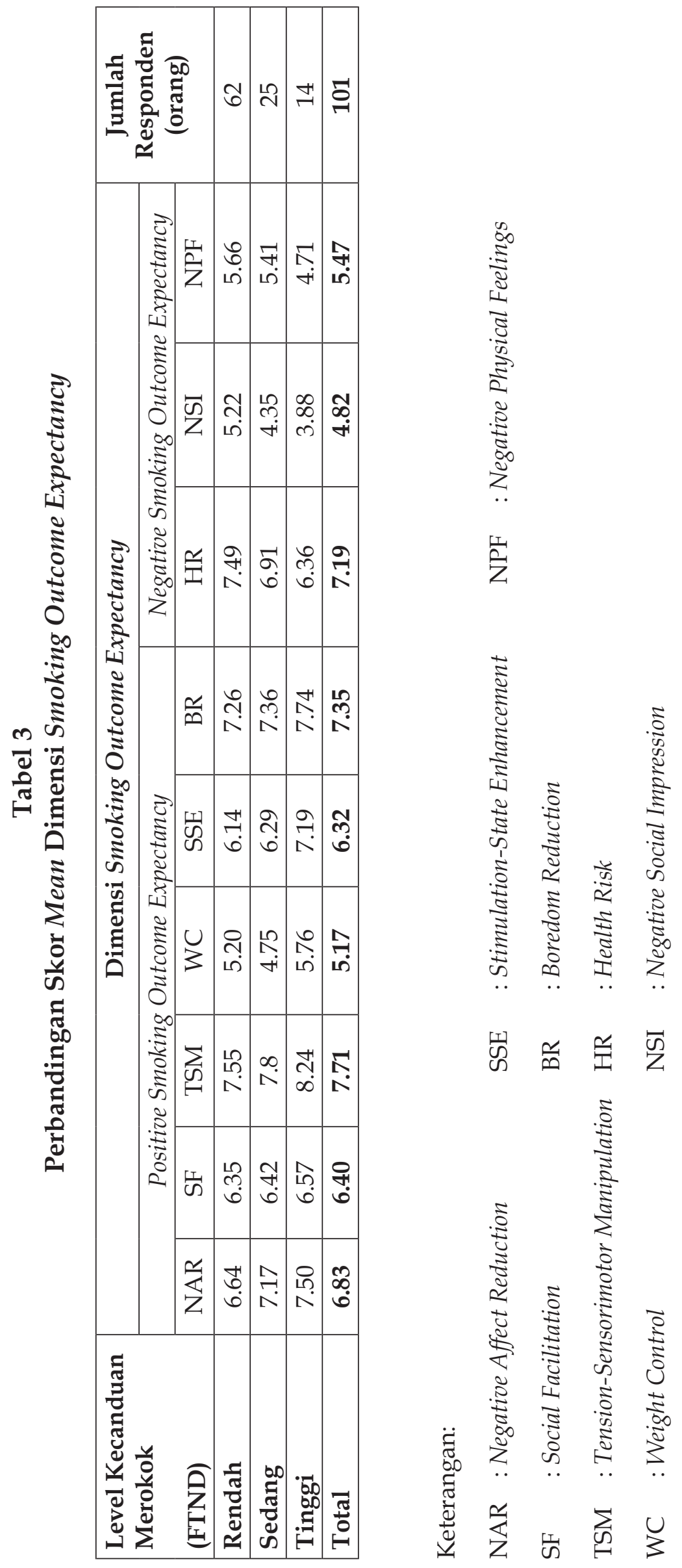


Tabel 4

Perbandingan Skor Mean Pengetahuan tentang Bahaya Merokok

\begin{tabular}{|c|c|c|}
\hline $\begin{array}{c}\text { Level Kecanduan } \\
\text { Merokok (FTND) }\end{array}$ & $\begin{array}{c}\text { Skor Mean } \\
\text { General Knowledge of Smoking }\end{array}$ & Jumlah Responden (orang) \\
\hline Rendah & 9.37 & 62 \\
\hline Sedang & 8.36 & 25 \\
\hline Tinggi & 7.79 & $\mathbf{1 0 1}$ \\
\hline Total & $\mathbf{8 . 9 0}$ & \\
\hline
\end{tabular}

Berdasarkan perbandingan nilai mean pengetahuan tentang bahaya merokok pada setiap level kecanduan merokok didapatkan hasil berupa skor rata-rata pengetahuan tentang bahaya merokok pada perokok dewasa muda yang kecanduan rokok merokok pada level tinggi adalah paling rendah $(\mathrm{M}=7.79$ dengan nilai minimum 2 dan nilai maksimum 12) dibandingkan dengan skor ratarata pengetahuan tentang bahaya merokok pada perokok dewasa muda yang kecanduan merokok pada level sedang $(M=8.36$ dengan nilai minimum 2 dan nilai maksimum 12) dan level rendah ( $M=9.37$ dengan nilai minimum 2 dan nilai maksimum 12) (lihat tabel 4.5.). Perbandingan nilai mean pengetahuan tentang bahaya merokok pada setiap level kecanduan merokok didapatkan hasil berupa skor rata-rata pengetahuan tentang bahaya merokok pada perokok dewasa muda yang kecanduan rokok merokok pada level tinggi adalah paling rendah ( $M=7.79$ dengan nilai minimum 2 dan nilai maksimum 12) dibandingkan dengan skor ratarata pengetahuan tentang bahaya merokok pada perokok dewasa muda yang kecanduan merokok pada level sedang $(M=8.36$ dengan nilai minimum 2 dan nilai maksimum 12) dan level rendah ( $M=9.37$ dengan nilai minimum 2 dan nilai maksimum 12).

\section{Tabel 5}

Perbedaan Positive Smoking Outcome Expectancy, Negative Smoking Outcome Expectancy, dan Pengetahuan Bahaya Merokok pada Perokok Dewasa Muda yang Kecanduan Merokok pada Level Tinggi dan Level Rendah

\begin{tabular}{|l|c|c|}
\hline & F & Sig (2-tailed) \\
\hline Positive Smoking Outcome Expectancy & & \\
\hline Equal variance assumed & 0.170 & 0.682 \\
\hline Negative Smoking Outcome Expectancy & & \\
\hline Equal variance assumed & 0.194 & 0.664 \\
\hline Pengetahuan tentang Bahaya Merokok & & \\
\hline Equal variance assumed & 0.797 & 0.375 \\
\hline
\end{tabular}

Perhitungan independent sample t-test untuk membandingkan positive smoking outcome expectancy pada kelompok responden yang kecanduan merokok pada level tinggi dan kelompok responden yang kecanduan merokok pada level rendah didapatkan koefisien signifikansi $F$ sebesar 0.170 tidak signifikan pada $\mathrm{p} \leq 0.05$. Hasil perhitungan menunjukkan tidak terdapat perbedaan positive smoking 
outcome expectancy pada kelompok responden yang kecanduan merokok pada level tinggi dan kelompok responden yang kecanduan merokok pada level rendah.

Perhitungan untuk membandingkan negative smoking outcome expectancy pada kelompok responden yang kecanduan merokok pada level tinggi dan kelompok responden yang kecanduan merokok pada level rendah didapatkan koefisien signifikansi F sebesar 0.194 tidak signifikan pada $p \leq 0.05$. Hasil perhitungan menunjukkan tidak terdapat perbedaan negative smoking outcome expectancy pada kelompok responden yang kecanduan merokok pada level tinggi dan kelompok responden yang kecanduan merokok pada level rendah.

Perbandingan pengetahuan tentang bahaya merokok pada kelompok responden yang kecanduan merokok pada level tinggi dan kelompok responden yang kecanduan merokok pada level rendah didapatkan koefisien signifikansi $\mathrm{F}$ sebesar 0.797 tidak signifikan pada $\mathrm{p} \leq 0.05$. Hasil perhitungan menunjukkan bahwa tidak terdapat perbedaan pengetahuan tentang bahaya merokok pada kelompok responden yang kecanduan merokok pada level tinggi dan kelompok responden yang kecanduan merokok pada level rendah.

Tabel 6

Perbedaan Positive Smoking Outcome Expectancy, Negative Smoking Outcome Expectancy, dan Pengetahuan tentang Bahaya Merokok pada Perokok Lakilaki dan Perokok Perempuan

\begin{tabular}{|l|c|c|}
\hline & F & Sig (2-tailed) \\
\hline Positive Smoking Outcome Expectancy & & \\
\hline Equal variance assumed & 0.56 & 0.453 \\
\hline Negative Smoking Outcome Expectancy & & \\
\hline Equal variance assumed & 0.194 & 0.664 \\
\hline Pengetahuan tentang Bahaya Merokok & & \\
\hline Equal variance assumed & 0.797 & 0.375 \\
\hline
\end{tabular}

Berdasarkan perhitungan independent sample t-test untuk membandingkan positive smoking outcome expectancy pada kelompok responden perokok laki-laki dan perempuan didapatkan koefisien signifikansi F sebesar 0.56 tidak signifikan pada $\mathrm{p} \geq 0.05$. Sedangkan untuk melihat perbedaan negative outcome expectancy pada kelompok responden perokok laki-laki dan perempuan didapatkan koefisien signifikansi F sebesar 0.56 tidak signifikan pada $p \geq 0.05$. Begitu pula dengan pengetahuan tentang bahaya merokok, Berdasarkan perhitungan independent sample t-test untuk membandingkan pengetahuan tentang bahaya merokok pada kelompok responden laki-laki dan perempuan didapatkan koefisien signifikansi $\mathrm{F}$ sebesar 1.988 tidak signifikan pada $\mathrm{p} \leq 0.05$.

\section{Diskusi}

Penelitian menemukan bahwa tidak terdapat korelasi negatif antara positive smoking outcome expectancy dan pengetahuan terhadap bahaya merokok pada 
perokok dengan level kecanduan tinggi, sedang, dan rendah. Korelasi antarvariabel itu positif dan tidak signifikan. Pengetahuan terhadap bahaya merokok merupakan bagian dari faktor kognisi yaitu penghubung antara lingkungan sosial dengan perilaku merokok. Faktor kognisi ini terdiri dari self-efficacy expectancy dan outcome expectancy (Petraitis dkk. 1995). Self-efficacy expectancy merupakan salah satu bagian dari komponen pengetahuan terhadap bahaya merokok. Pada orang yang telah kecanduan merokok dimungkinkan pengetahuan tentang bahaya merokok sudah tidak lagi mempengaruhi perilaku merokoknya. Konsekuensi positif dari perilaku merokok menjadi dominan dari dirinya karena lebih memberikan kenyamanan fisik sementara, seperti pikiran terasa rileks. Penelitian dari Jeffries, dkk. (2004) yang menemukan bahwa positive smoking outcome expectancy meningkat apabila dihubungkan dengan level kecanduan merokok. Hasil penelitian tersebut sejalan dengan hasil penelitian ini yang menunjukkan bahwa semakin tinggi positive smoking outcome expectancy, semakin tinggi level kecanduan merokok pada dewasa muda.

Expectation of reinforcement atau positive outcome expectancy dan tingkah laku penggunaan zat adiktif tertentu (misalnya, nikotin pada rokok) berkorelasi dengan memori sebagai sebuah skema kognitif (Palfai 2002). Pengetahuan sebagai bagian dari skema kognitif berkorelasi dengan positive smoking outcome expectancy, namun pada penelitian ini korelasinya tidak signifikan. Informasi tentang expectancy menjadi lebih teraktivasi dan mempengaruhi tingkat penggunaan zat adiktif (misalnya, nikotin pada rokok) akan diprediksi oleh stimulus eksternal yang disediakan oleh lingkungan dan perbedaan setiap individu dalam aksesibilitas informasi tentang zat tersebut berdasarkan level kecanduan merokok (Stacy, Leigh, dan Weingardt 1994). Hasil yang tidak signifikan antara positive smoking outcome expectancy dan pengetahuan tentang bahaya merokok dimungkinkan karena adanya perbedaan aksesibilitas informasi tentang perilaku merokok yang berbeda-beda pada setiap perokok berdasarkan level kecanduan merokoknya.

Pada dimensi positive smoking outcome expectancy yang memiliki skor ratarata tertinggi secara berurutan adalah taste-sensorimotor manipulation, boredome reduction, dan negative affect reduction. Sedangkan, pada penelitian Copeland dkk. (1995) menunjukkan bahwa terdapat korelasi positif antara dimensi negative affect reduction dan stimulation-state enhancement dengan level kecanduan merokok pada orang dewasa. Hasil temuan yang sama adalah dimensi negative affect reduction. Negative affect reduction merupakan positive smoking outcome expectancy yang paling banyak ketiga dipilih oleh sampel penelitian. Sedangkan, hasil penelitian yang berbeda adalah pada dimensi taste-sensorimotor manipulation dan boredome reduction mendapatkan hasil yang paling banyak dipilih sampel penelitian ini sedangkan pada penelitian Copeland dkk. (1995) hanya beberapa individu yang memilihnya. Hal ini kemungkinan adanya perbedaan positive smoking outcome expectancy pada perokok Indonesia, khusunya daerah Depok yang menjadi responden penelitian ini dengan perokok Caucasian yang menjadi responden Copeland dkk. (1995). Namun, pada penelitian ini tidak dapat dijelaskan faktor apa yang membuat berbeda pada karakteristik dua kelompok perokok tersebut, 
seperti jenis rokok yang biasa dihisap (misalnya, orang African American lebih memilih rokok menthol).

Penelitian menemukan bahwa ada korelasi positif antara negative smoking outcome expectancy dan pengetahuan terhadap bahaya merokok pada perokok dewasa muda. Pengetahuan terhadap bahaya merokok berhubungan dengan dimensi health risk dan negative physical feelings. Pada komponen pengetahuan terhadap bahaya merokok terdiri dari pengetahuan tentang pengaruh asap rokok secara langsung terhadap diri perokok, pengetahuan tentang pengaruh asap rokok terhadap perokok pasif, pengetahuan tentang intensitas dan durasi merokok bagi perokok, dan pengetahuan tentang keyakinan kemudahan dan manfaat dari berhenti merokok atau self-efficacy (Martini dan Sulistyowati 2005) yang setiap itemnya merupakan bagian dari health risk dan negative physical feeling namun dalam bentuk ability test. Hasil tambahan pada penelitian ini adalah semakin tinggi negative smoking outcome expectancy, semakin tinggi pengetahuannya terhadap bahaya merokok pada perokok dewasa muda dan hasilnya signifikan. Berdasarkan hasil analisis tambahan ditemukan bahwa semakin tinggi level kecanduan merokok seseorang maka semakin rendah negative smoking outcome expectancy yang ada pada dirinya. Secara umum, hasil penelitian temuan tersebut sejalan dengan hasil penelitian Copeland dkk. (1995) dan Jeffries dkk. (2004) yang menemukan bahwa negative smoking outcome expectancy menurun apabila dihubungkan dengan level kecanduan merokok.

Pada dimensi negative smoking outcome expectancy yang paling banyak dipilih oleh responden penelitian ini secara berurutan dari tertinggi sampai dengan terendah adalah health risk, negative physical feelings, dan negative social impression. Sedangkan, pada penelitian Jeffries dkk. (2004) menunjukkan bahwa health risk, negative social impression, dan negative physical feelings secara berurutan dengan level kecanduan merokok pada orang dewasa. Terdapat perbedaan pada dimensi negative social impression. Pada penelitian Jeffries dkk. (2004) merupakan variabel tertinggi sedangkan dimensi negative smoking outcome expectancy terendah pada penelitian ini. Hal ini dimungkinkan pada responden di Indonesia, mereka tidak merasa bahwa merokok merupakan perilaku yang dinilai negatif dipandang lingkungan orang-orang sekitarnya. Iklan televisi memberikan dampak yang besar terhadap gaya hidup perilaku merokok di masyarakat sehingga negative social impression menjadi dimensi yang paling rendah dinilai oleh responden penelitian. Iklan rokok di Indonesia kebanyakan menampilkan laki-laki yang maskulin dan berani menghadapi tantangan serta perempuan yang seksi dan menarik. Dengan adanya image perilaku merokok yang seperti digambarkan di iklan semakin membuat seseorang tertarik untuk merokok dan menguatkan perilakunya.

\section{Kesimpulan}

Kesimpulan dari hasil analisis penelitian ini, antara lain gambaran responden pada level kecanduan merokok tinggi, sedang, dan rendah berdasarkan positive smoking outcome expectancy menunjukkan bahwa terdapat tiga dimensi yang paling banyak dinilai positif, yaitu taste-sensorimotor manipulation, boredome reduction, 
dan negative affect reduction. Sedangkan, pada negative smoking outcome expectancy menunjukkan bahwa health risk, negative physical feeling, dan negative social impression secara berurutan menduduki urutan tertinggi sampai dengan terendah yang dinilai paling banyak oleh responden pada level kecanduan merokok tinggi, sedang, dan rendah. Gambaran responden penelitian dengan level kecanduan merokok rendah, sedang, dan tinggi menunjukkan bahwa pengetahuan tentang bahaya merokok secara berurutan dari yang tertinggi sampai dengan terendah. Dua pertanyaan utama pada penelitian ini dijawab dengan hasil penelitian, yaitu pertama tidak terdapat hubungan negatif antara positive smoking outcome expectancy dan pengetahuan terhadap bahaya merokok pada dewasa muda yang merokok. Kedua, terdapat hubungan positif yang signifikan antara negative smoking outcome expectancy dan pengetahuan terhadap bahaya merokok pada dewasa muda yang merokok. Berdasarkan perbedaan smoking outcome expectancy dan pengetahuan tentang bahaya merokok pada perokok dewasa muda yang kecanduan pada level tinggi dan rendah menunjukkan, yaitu tidak terdapat perbedaan positive smoking outcome expectancy, negative smoking outcome expectancy, dan pengetahuan tentang bahaya merokok pada kelompok perokok dewasa muda yang kecanduan merokok pada level tinggi dan level rendah.

Dari hasil penelitian terdapat temuan yang tidak signifikan antara positive smoking outcome expectancy dan pengetahuan tentang bahaya merokok. Hal ini dimungkinkan pengetahuan tentang bahaya merokok bukan merupakan prediktor utama bagi perilaku merokok dan smoking outcome expectancy. Bagi orang yang merokok dengan level kecanduan tinggi, pengetahuan sudah tidak mempengaruhi perilakunya. Kebutuhan dirinya terhadap perilaku merokok bisa menjadi coping stress atau mekanisme biologis tubuhnya.

Hubungan positif yang signifikan antara negative smoking outcome expectancy dengan pengetahuan tentang bahaya merokok. Hasil ini dapat dijadikan masukan untuk meningkatkan kampanye anti rokok dengan memasukkan unsur negative smoking outcome expectancy, seperti health risk, negative social impression, dan negative physical feelings dan peningkatan pengetahuan tentang bahaya merokok. Semakin tingginya pengetahuan tentang bahaya merokok diharapkan dapat meningkatkan konsekuensi negatif dari perilaku merokok. Pada dimensi positive smoking outcome expectancy yang mendapatkan nilai tertinggi adalah taste-sensorimotor manipulation, boredome reduction, dan negative affect reduction. Para konselor adiksi merokok, maupun para perokok yang ingin berhenti merokok dapat menyarankan suatu kegiatan tertentu untuk menggantikan harapan taste-sensorimotor manipulation, boredome reduction, dan negative affect reduction yang didapatkan dari rokok dengan kegiatan lain yang menimbulkan perasaan atau sensasi yang sama.

Apabila terdapat perokok yang merasa bahwa smoking outcome expectancy yang ada pada dirinya bukan merupakan salah satu dari temuan tertinggi pada penelitian ini, konselor adiksi dapat melakukan asesmen dengan menggunakan alat ukur Smoking Consequence Quessionaire-Adult (SCQ-A) sebagai data tambahan untuk membantu mencari kegiatan yang dapat menggantikan perilaku merokok sesuai dengan outcome expectancy orang tersebut. 


\section{Daftar Pustaka}

American Psychiatric Association. 2000. Diagnostic and statistical manual of mental disorders (4th ed., Text Revision). Washington, DC: Author.

Bandura, A. 1986. Social Foundations of Thought and Action: A Social Cognitive Theory. Englewood Cliffs, NJ: Prentice Hall.

Bandura, A. 1999. A sociocognitive analysis of substance abuse: An agentic perspective. Psychological Science, 10, 214-217. https://doi.org/10.1111/1467$\underline{9280.00138}$

Brandon, T. H., dan Baker, T. B. 1991. The smoking consequences questionnaire: The subjective expected utility of smoking in college students. Psychological Assessment: A Journal of Consulting and Clinical Psychology, 3(3), 484-491. https://doi.org/10.1037/1040-3590.3.3.484

Conner, M., dan Norman, P. 1996. The role of social cognition in health behaviour. Dalam M. Connner \& P. Norman (Eds.), Predicting Health Behaviour (hal. 1-22). Buckingham: Open University Press.

Copeland, A. L., Brandon, T. H., dan Quinn, E. P. 1995. The smoking consequences questionnaire-adult: Measurement of smoking outcome expectancies of experienced smokers. Psychological Assessment, 7(4), 484-494. https://doi. org/10.1037/1040-3590.7.4.484

Donovan, J. E., Jessor, R., dan Costa, F. M. 1988. Syndrome of problem behavior in adolescence: A replication. Journal of Consulting and Clinical Psychology, 56(5), 762-765. https://doi.org/10.1037/0022-006X.56.5.762

Fagerstro“m, K. O., Heatherton, T. F., \& Kozlowski, L. T. 1992. Nicotine addiction and its assessment. Ear, Nose, and Throat Journal, 69, 763-767.

Goldman, M. S. 2002. Expectancy and risk for alcoholism: The unfortunate exploitation of a fundamental characteristic of neurobehavioral adaptation. Alcoholism: Clinical and Experimental Research, 26(5), 737-746. https://doi. org/10.1111/j.1530-0277.2002.tb02599.x

Goldman, M. S., Del Boca, F. K., dan Darkes, J. 1999. Alcohol expectancy theory: The application of cognitive neuroscience. Dalam K. E. Leonard \& H.T. Blane (Eds.), Psychological Theories of Drinking and Alcoholism (2nd ed.) (hal. 203-246). New York: Guildford Press.

Grinder, R. E. 1978. Adolescence ( $2^{\text {nd }}$ ed.). Canada: John Willey \& Sons, Inc.

Jeffries, S. K., dkk. 2004. Use of a Brief Smoking Consequences Questionnaire for Adults (SCQ-A) in African American Smokers. Psychology of Addictive Behaviors, 18(1), 74-77. https://doi.org/10.1037/0893-164X.18.1.74

Kaplan, R. M., Sallis, J. J. F., dan Ratterson. 1993. Health and Human Behavior. New York: McGraw-Hill.

Martíni, S., dan Sulistyowati, M. 2005. The determinants of smoking behavior among teenagers in East Java Province, Indonesia. The Economic Tobbaco 
Control. Washington DC: The World Bank.

Papalia, D. E., Olds, S. W., dan Feldman, R. D. 2009. Human Development $11^{\text {th }}$ Edition. New York: McGraw-Hill.

Petraitis, J., Flay, B. R., dan Miller, T. 1995. Reviewing theories of adolescent substance use: Organising pieces in the puzzle. Psychological Bulletin, 117(1), 67-86. DOI: 10.1037/0033-2909.117.1.67

Pollay, R. W. 2000. How Cigarette Advertising Works: Rich Imagery and Poor Information. Vancouver: University of British Columbia.

Reig-Ferrer, A., dan Cepeda-Benito, A. 2007. Smoking expectancies in smokers and never smokers: An examination of the smoking Consequences Questionnaire-Spanish. Addictive Behaviors, 32(7), 1405-1415. https://doi. org/10.1016/j.addbeh.2006.10.004

Rice, F. P. 1990. The Adolescence ( $6^{\text {th }}$ ed.). Boston: Allyn \& Bacon.

Sarafino, E. P. 1990. Health Psychology: Biopsychosocial Interaction. United States of America: John Willey \& Sons, Inc. 


\section{Pedoman Penulisan}

Naskah artikel ditulis dalam bahasa Indonesia atau bahasa Inggris dengan panjang 5000-8000 kata. Lebih dari 8000 kata ditoleransi dengan catatan bahwa kelebihan tersebut sepadan dengan data, informasi, serta analisis dan diskusi yang dikerjakan. Naskah merupakan hasil penelitian maupun refleksi kritis atas sebuah pemikiran, teori, atau metodologi dalam sosiologi atau ilmu sosial secara umum. Penting diingat bahwa naskah yang diajukan tidak tengah dalam proses pengajuan atau dalam proses telaah (review) di jurnal lain. Pengajuan naskah artikel dilakukan melalui menu submission (pengajuan) di website http://journal.unusia.ac.id/index.php/Muqoddima.

Naskah ditulis dengan menggunakan font Book Antiqua pada program Microsoft Word, dengan ekstensi .doc, .docx, atau .rtf. Sistem penulisan secara umum adalah sebagai berikut:

\section{Judul}

Judul merefleksikan isi tulisan, singat, padaat dan diupayakan menarik minat pembaca. Font sebesar 20 poin, dengan huruf kapital di depan setiap kata (Capitalized Each Word) kecuali kata sambung. Panjang judul tidak lebih dari 10 kata. Hindari menggunakan tanda kurung (...) dalam judul.

\section{Nama dan identitas penulis}

Nama lengkap penulis dicantumkan tanpa gelar akademik, disertai keterangan institusi dan alamat email.

\section{Abstrak dan kata kunci}

Abstrak ditulis dalam bahasa Indonesia dan bahasa Inggris dengan panjang antara 150-250 kata. Abstrak seutuhnya ditulis dalam bentuk naratif memuat kajian, tujuan penelitian, metodologi, temuan, dan argumentasi. Kata kunci maksimal terdiri atas 6 (enam) kata/frasa.

\section{Tubuh artikel}

Tubuh artikel ditulis dengan ukuran huruf 11 poin, kecuali untuk sub judul (13 poin) dan catatan kaki (10 poin). Setiap awal paragraf ditulis menjorok ke dalam sepanjang 1 $\mathrm{cm}$. Penggunaan kata-kata asing dituliskan secara miring (italic). Tubuh artikel memuat empat komponen pokok meliputi (1) pendahuluan, (2) metode/cara kerja, (3) analisis dan diskusi, dan (4) kesimpulan.

\section{Catatan kaki}

Catatan kaki dituliskan hanya jika diperlukan, yakni untuk memberikan keterangan tambahan atasu suatu hal spesifik yang tidak sinambung secara langsung bila diletakkan sebagai bagian tubuh artikel. Hindari menggunakan catatan kaki jika berkenaan dengan sumber rujukan teoritis atau sumber data primer.

\section{Daftar Pustaka}

Daftar Pustaka ditulis dengan mengikuti standar format ASA (American Sociological Association). Format ASA juga berlaku dalam penulisan kutipan di tubuh artikel, termasuk 
catatan perut dan catatan kaki (note, footnote).

Berikut ini adalah berapa contoh penulisan isi Daftar Pustaka:

Andreassen A., Bard. 2007. "Human Rights and Legal Empowerment of the Poor", Extreme Poverty and Human Rights Expert Seminar, Geneva 23-24 February 2007, Norwegian Centre for Human rights, University of Oslo.

Fatoni, Muhammad Sulton. 2015. Kapital Sosial Pesantren (Studi Tentang Komunitas Pesantren Sidogiri Pasuruan Jawa Timur). Jakarta: Universitas Indonesia.

Geertz, Clifford. 1965. "Religion: Anthropological Study", dalam David L. Sills (ed.) International Encyclopedia of the Social Sciences. London: Collier-Macmillan Publishers.

Jones, Bobby L., Daniel S. Nagin, dan Kathryn Roeder. 2001. “A SAS Procedure Based on Mixture Models for Estimating Developmental Trajectories." Sociological Methods and Research 29 (3):374-93. Diakses pada 26 April 2005 (https://journals.sagepub. com/doi/10.1177/0049124101029003005).

Kukathas, Chandran. 2002. "Multiculturalism as Fairness: Will Kymlicka's Multicultural Citizenship." Journal of Political Philosophy 5(4):406-427. Diakses pada 27 Mei 2019. (https://onlinelibrary.wiley.com/doi/10.1111/1467-9760.00041)

Keterangan lebih rinci terkait ketentuan penulisan dapat diperiksa dalam Template Artikel MJPRS. 


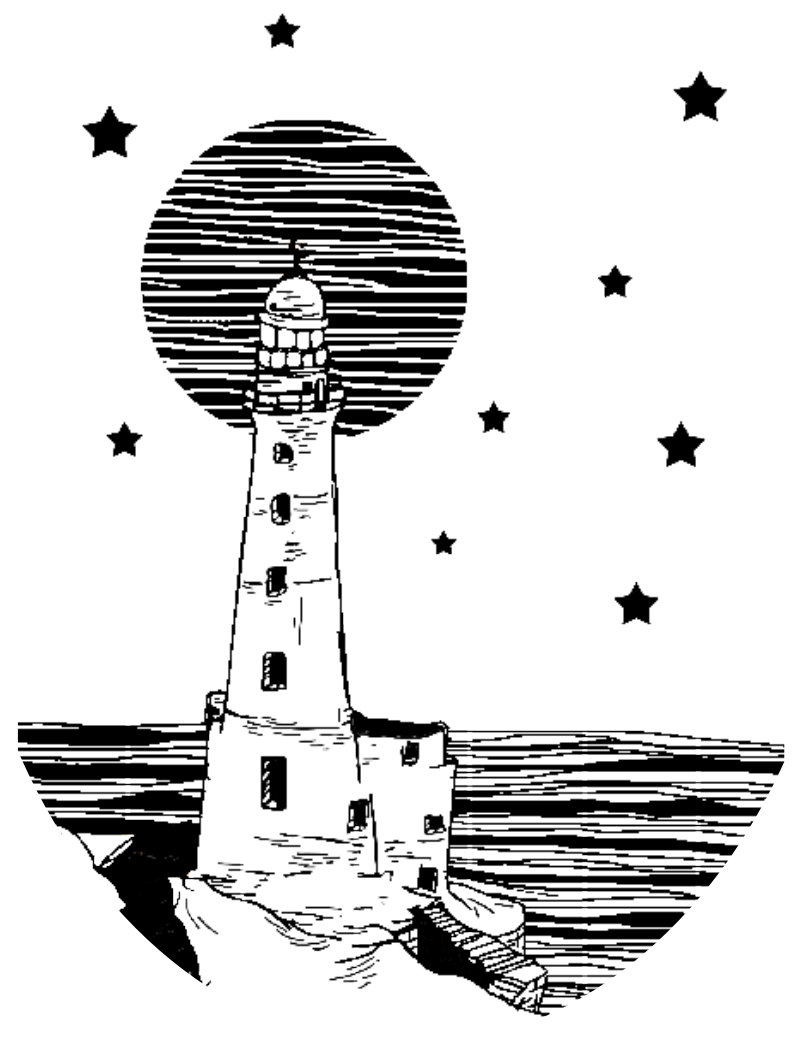



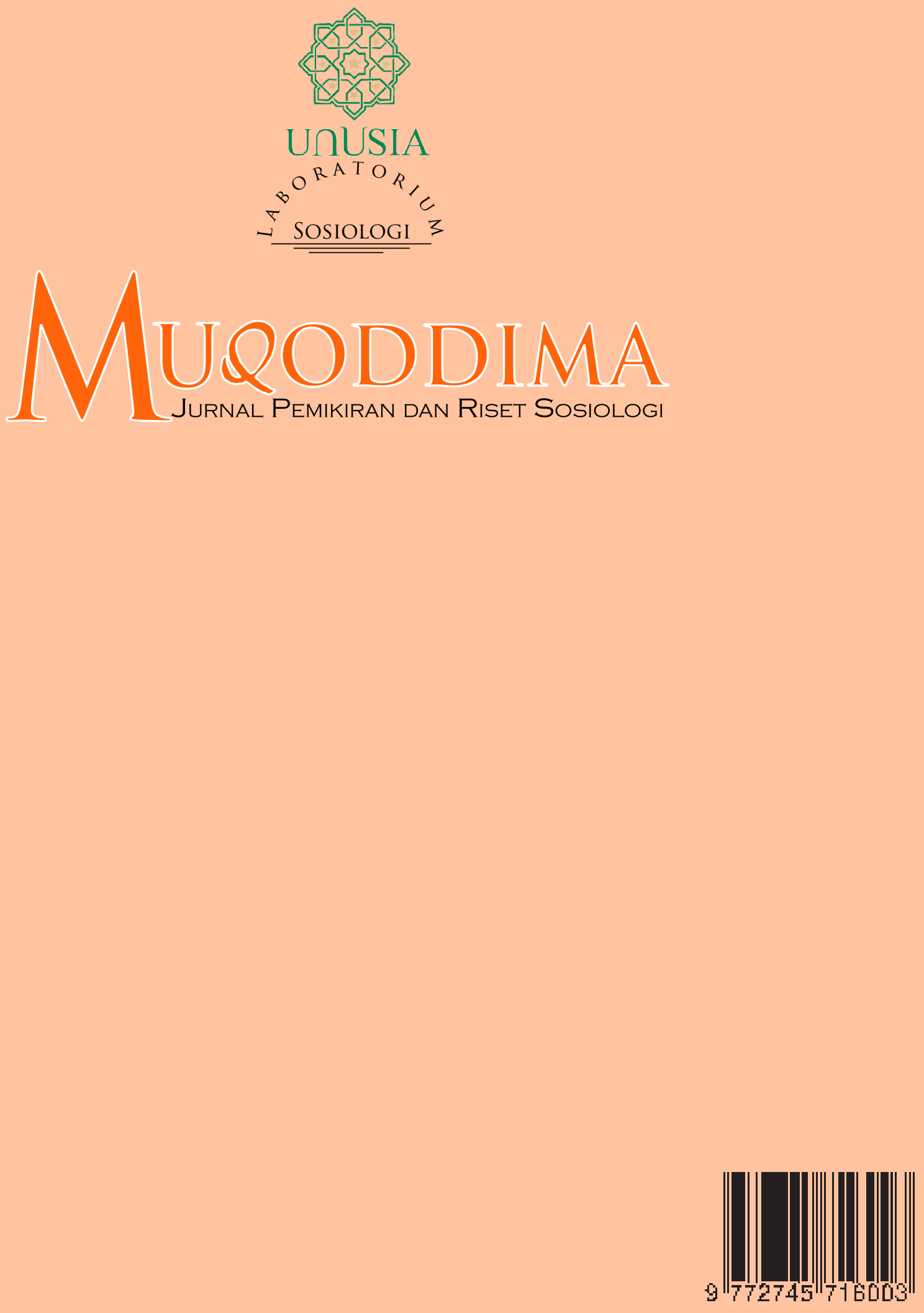